\title{
Efficacy of Chlorine on Multiple Species of Phytophthora in Recycled Nursery Irrigation Water
}

C. X. Hong, P. A. Richardson, P. Kong, and E. A. Bush, Department of Plant Pathology, Physiology, and Weed Science, Virginia Polytechnic Institute and State University, Hampton Roads Agricultural Research and Extension Center, Virginia Beach 23455

\begin{abstract}
Hong, C. X., Richardson, P. A., Kong, P., and Bush, E. A. 2003. Efficacy of chlorine on multiple species of Phytophthora in recycled nursery irrigation water. Plant Dis. 87:1183-1189.

Recycled irrigation water is a primary source of inoculum for Phytophthora spp. and is capable of spreading propagules throughout nursery production. Chlorination commonly is used by the industry to disinfest recycled irrigation water; however, chlorine has not been fully researched as a disinfestant for this purpose. In this study, zoospores of seven species and eight isolates of Phytophthora were exposed for $2 \mathrm{~min}$ to free available chlorine at $0.25,0.5,1.0,2.0$, and 4.0 $\mathrm{mg} / \mathrm{liter}$. Zoospores, mycelial fragments, and culture plugs of $P$. nicotianae also were exposed to chlorine concentrations ranging from 0.25 to $8.0 \mathrm{mg} /$ liter for periods ranging from $15 \mathrm{~s}$ to $8 \mathrm{~min}$. In addition, chlorinated water was assayed monthly in 2000 and 2001 at two commercia nurseries, and quarterly in the first year at four other nurseries in Virginia, for chlorine and survival of pythiaceous species using a selective medium. No zoospores of any species tested survived endpoint free chlorine at $2 \mathrm{mg} /$ liter, while limited mycelial fragments of $P$. nicotianae survived at $8 \mathrm{mg} /$ liter, and mycelial plugs treated at the same level of chlorine were able to produce few sporangia. Phytophthora spp. were recovered only from nursery irrigation water with levels of free chlorine at $0.77 \mathrm{mg} /$ liter or lower. The results of this study are essential for improving current chlorination protocols.
\end{abstract}

Additional keywords: chlorine demand, chlorine species, disinfestation, recycling irrigation

Recycling irrigation is of critical importance to the ornamental crop nursery industry due to increasing global water scarcity and for protection of limited water resources (39). However, using nondisinfested recycled water for irrigation can result in serious disease epidemics and crop losses, as reported for Phytophthora blight on annual vinca (Catharanthus roseus L.) (21). Although chemical control of Phytophthora diseases with fosetyl-Al and metalaxyl is effective, it is expensive (15). Overuse of these fungicides increases the risk of development of fungicide resistance. More importantly, plants may appear healthy while treated under intensive fungicide programs, but still harbor inoculum, which can proliferate when prophylactic fungicides are discontinued.

Corresponding author: C. X. Hong

E-mail: chhong2@vt.edu

This study was supported in part by an Environment Protection Agency/Virginia Department of Conservation and Recreation grant C9-003499010 , a United States Department of Agriculture/Southern Region Integrated Pest Management Special Grants Program grant 00-34103-9052, the Virginia Agricultural Council, and the Virginia Nursery and Landscape Association.

Accepted for publication 5 May 2003.

Publication no. D-2003-0714-04R

(C) 2003 The American Phytopathological Society
After sale, plants commonly receive no fungicide treatment, while simultaneously facing environmental stresses, and often succumb to disease. Therefore, decontamination of recycled water prior to use for irrigation and other preventive phytosanitary methods are warranted to ensure viability of the horticultural industry.

Among numerous plant pathogens that can be spread through irrigation water, Phytophthora spp. have been the focus of previous investigations. Phytophthora spp. detected from different components of recycling nursery irrigation systems to date include: P. cactorum (Lebert \& Cohn) J. Schröt. $(3,18)$, P capsici Leonian $(3,18), P$. cinnamomi Rands $(27,30,50)$, $P$. citricola Sawada $(3,18,30,50)$, P. citrophthora (R. E. Sm. \& E. H. Sm.) Leonian $(3,18,30,50), P$. cryptogea Pethybr. \& Lafferty $(3,18,27$, 30,50), $P$. drechsleri Tucker $(3,18), P$. gonapodyides (Petersen) Buisman (34), $P$. megasperma Drechs. (18,30), P. nicotianae (Brenda de Haan) Dastur (3,18,27,30, 45,50), and $P$. syringae (Kleb.) Kleb. (30). $P$. cinnamomi also was detected in rivers $(24,48)$. The populations of individual species may range from a few to over a thousand CFU/liter, depending on plant species growing on property, history of recycling irrigation runoff, the time of year, and a number of other factors. However, even undetectable levels of these pathogens in irrigation water can cause severe Phytophthora blight on ornamental crops $(19,21)$, a result of repeated exposure of these crops to the same pathogens $(20,29)$.

In contrast to Phytophthora spp., other plant pathogens in recycling nursery irrigation systems are largely unknown. The presence of Pythium spp. in recycling irrigation systems has been noted, mostly in work addressing Phytophthora spp. $(3,18,27,30,31,45)$. The identities, pathogenicity, and significance to ornamental crops of these species have not been thoroughly evaluated. Among bacterial pathogens, Erwinia spp. have been isolated in nursery irrigation systems $(26,32)$. There has been little study on fungal, nematodal, and viral pathogens in nursery irrigation water, although they have been detected in water supplies and irrigation systems of other crops $(12,25,47)$. Nematode survival and infectivity was significantly reduced after passing through overhead sprinkler irrigation systems (16). Thus, removal of Phytophthora spp. has legitimately become an immediate objective of recycled irrigation water treatment.

Current methods for disinfesting irrigation water include (i) filtration, (ii) ultraviolet irradiation, (iii) ozonation, (iv) nonionic surfactants, (v) chlorination, and (vi) alternatives such as acidic electrolyzed oxidizing water (2) and calcium (49). Each method has advantages and limitations. Filtration, especially slow sand filtration, is effective in removing some fungi, bacteria, and even a virus (37), but has been of limited use due to its low capacity and high maintenance requirement. Filtration currently is used in combination with other methods, such as ultraviolet irradiation (14) and chlorination (15). Ultraviolet irradiation reduces plant pathogens $(5,11,14$, 29,36), and its effectiveness is dependent upon water flow rate and solid organic content in irrigation water $(5,9)$. Ozonation also effectively eliminates some plant pathogens in irrigation water but it has not been widely adopted due to its high cost in establishment $(29,52)$. Nonionic surfactants, through inhibitory and lytic effects (43), effectively controls root rots of pepper and cucumber, caused respectively by $P$. capsici (41) and Pythium aphanidermatum (Edson) Fitzp. (42), in recirculating hydroponic systems. However, the applicability of this technology to nursery production is yet to be investigated. Chlorination is the most economical water 
decontamination method but specific recommendations for use in nursery irrigation are lacking. This technology was initially developed, and remains, as one of the primary methods for treating municipal water $(23,28,44,51)$. The adoption of this technology by growers for irrigation systems has become widespread in the nursery industry, but it has not been fully assessed for control of plant pathogens.

Previous investigations, although limited, have demonstrated clearly that chlorine sensitivity can differ with species, pathovar, and type of propagules of the same pathogens. E. carotovora subsp. zeae Sabet was extremely sensitive to chlorine, and chlorine at $1 \mathrm{mg} / \mathrm{liter}$ was an adequate concentration to insure control of bacterial stalk rot of corn (Zea mays L.) under most conditions (46). E. chrysanthemi Burkholder et al. and E. carotovora subsp. carotovora (Jones) Bergey were less sensitive, and survived at $10 \mathrm{mg} / \mathrm{liter}$ (26). In another study conducted with a hydroponic system, chlorine at $3 \mathrm{mg} / \mathrm{liter}$ reduced the total counts of bacteria by $80 \%$ (11). Two types of spores of Thielaviopsis basicola (Berk. \& Broome) Ferraris had rather different sensitivities: chlorine at 1 to 3 $\mathrm{mg} / \mathrm{liter}$ resulted in $95 \%$ mortality of endoconidia, while 34 to $58 \mathrm{mg} /$ liter caused only $90 \%$ mortality of aleuriospores (6). Sensitivity to chlorine also can vary with exposure time $(6,7,38,40)$. Similar variations have been found with Phytophthora spp. (40). In addition, chlorine efficacy depends on temperature and $\mathrm{pH}(33,38)$.

A major gap in this research data is lack of chlorinated irrigation water tests. There also are problems with consistency between field tests and lab chlorine assays. To our knowledge, the only tests of chlorinated irrigation water targeting Phytophthora spp. were conducted in citrus orchards. Two levels of free chlorine, 50 $\mathrm{mg} / \mathrm{liter}$ alone or $10 \mathrm{mg} / \mathrm{liter}$ combined with filtration, provided effective control of the target pathogens (15). These chlorine levels appear considerably different from the lethal doses for Phytophthora spp. obtained from lab assays. For example, the lethal doses of chlorine were $1 \mathrm{mg} / \mathrm{liter}$ for zoospores and 100 to $200 \mathrm{mg} /$ liter for mycelium of $P$. cinnamomi, depending on contact time (40). A similar low lethal dose (2 $\mathrm{mg} / \mathrm{liter}$ ) also was observed for zoospores of $P$. nicotianae (17). As a result of this sparse and inconsistent research data, diverse chlorination protocols have been implemented $(8,35,39)$ and growers are uncertain if they achieve effective pathogen control. Assessment of existing chlorination protocols will provide information on two important questions. What is the minimal level of free available chlorine for effective control of Phytophthora spp. in irrigation water, and are other Phytophthora spp. commonly present in irrigation water as sensitive to chlorine as those tested previously?
Chlorine demand is an important consideration in chlorination protocols. Chlorine demand is the measure of the amount of chlorine which will be consumed by organic matter and other oxidizable substances in water before a chlorine residual can be established (50). Chlorine demand differs with type and amount of existing organics and inorganics in water. Chlorine demands of some inorganic elements recently were examined (6). However, irrigation water contains numerous and variable combinations of organics and inorganics. The chemistry of recycled irrigation water is complex and may differ with locality and season. Estimation of chlorine demand of irrigation water has yet to be generalized.

Choice of chlorine species to monitor also has a direct impact on chlorination efficacy. Common chlorine species include free available (residual) chlorine, combined residual chlorine, or total residual chlorine (50). Free available chlorine is composed of dissolved chlorine gas $\left(\mathrm{Cl}_{2}\right)$, hypochlorus acid $(\mathrm{HOCl})$, or hypochlorite ion $\left(\mathrm{OCl}^{-}\right)$remaining in water after chlorination. Combined residual chlorine is the chlorine that is combined with ammonia $\left(\mathrm{NH}_{3}\right)$ or organic nitrogen in water as chloramines or other chloro derivatives, yet is still available to oxidize organic matter and utilize biocidal properties. Compounds of combined residual chlorine include monochloramine, dichloramine, and nitrogen trichloride. These compounds are more stable but are somewhat less biocidal than free chlorine forms. Total residual chlorine is the sum of the free available chlorine and the combined residual chlorine. The same levels of different chlorine species may have rather different meanings in term of biocidal property, depending on the purity of water and consequent chlorine demand. Use of different chlorine species or unspecified species in some previous investigations has been a major source of confusion and may have caused misinterpretations and misuse of respective research data.

Phytotoxicity is another issue of great concern associated with chlorination. This is especially important for nursery production because individual nurseries grow numerous plant species, cultivars, and varieties with varying sensitivity to chlorine. High levels of chlorine can cause severe chemical injuries to plants (1), but it is generally considered that free available chlorine at $2.9 \mathrm{mg} / \mathrm{liter}$ is safe for most ornamental crops (39) and $4 \mathrm{mg} / \mathrm{liter}$ for rose culture (35). The critical question is whether these low levels of free available chlorine are adequate to achieve good control of major plant pathogens in recycled irrigation water.

The primary goal of this research was to assess the efficacy of chlorine on multiple species of Phytophthora, a group of destructive pathogens that can originate pri- marily in and spread through irrigation water and attack numerous ornamental crops. An additional goal was to clarify the confusion regarding chlorine measurement in field operations. Specifically, this research examined (i) chlorine demand of pathogen suspension in sterile soil water extract (SSWE), (ii) the effect of chlorine concentration on zoospores of multiple species of Phytophthora commonly found in irrigation water, (iii) the effects of chlorine concentration and contact time on survival of zoospores and mycelial fragments and effects on sporangium production of $P$. nicotianae, and (iv) the threshold level of chlorine at which Phytophthora spp. could be recovered in treated irrigation water at commercial nurseries in Virginia.

\section{MATERIALS AND METHODS}

Phytophthora spp. and cultures. Species evaluated for chlorine sensitivity included two isolates (1B11 and 4J1) of $P$. nicotianae and one isolate each of $P$. capsici, $P$. cinnamomi, $P$. citricola, $P$. citrophthora, $P$. cryptogea, and $P$. megasperma. Test isolates were recovered directly from nursery irrigation water or ornamental plants. Individual isolates were subcultured on clarified V8 agar in 10-cmdiameter petri dishes at $20^{\circ} \mathrm{C}$ for 4 days or 2 weeks, depending on the fungal propagule tested.

Chlorine assays and treatments. Zoospores and mycelium were assessed for mortality after chlorine treatment. Mycelium also was assessed for sporangium production following chlorine treatment. For mortality assays, chlorine treatments were accomplished by mixing $0.5 \mathrm{ml}$ of chlorine solution with $0.5 \mathrm{ml}$ of zoospore or mycelium suspension in a microtube on an Eppendorf mixer, then adding $12 \mu \mathrm{l}$ of corresponding sodium thiosulfate (Fisher Scientific, Pittsburgh) dilution to neutralize the residual chlorine in the solution. For sporangium production tests, chlorine treatments were accomplished by adding 5 $\mathrm{ml}$ of a chlorine solution to each of three cells in 60-mm multicell petri dishes containing three mycelial plugs per cell. Similarly, chlorine was neutralized by adding $120 \mu \mathrm{l}$ of corresponding sodium thiosulfate dilution.

Seven species (eight isolates) of Phytophthora were evaluated for zoospore mortality. Two-week-old cultures with numerous sporangia were used in zoospore mortality assays. P. nicotianae isolate $1 \mathrm{~B} 11$ was further assessed for mortality of mycelia and for sporangium production. Four-day-old cultures were used in these assays to eliminate possible interference by sporangia that can form on agar.

Chlorine demand of pathogen suspension. Fresh stock solution of chlorine (40 $\mathrm{mg} /$ liter) was prepared from bleach $(5.25 \%$ sodium hypochlorite) with sterile nanopure water (SDW) at $\mathrm{pH}$ 6.4. The solution was 
diluted with 1\% SSWE (pH 6.8) to chlorine concentrations of $0.5,1.0,2.0$, 4.0, 8.0, and $16.0 \mathrm{mg} / \mathrm{liter}$. Each diluted chlorine solution $(10 \mathrm{ml})$ was mixed equally (vol:vol) with a zoospore suspension of a test Phytophthora isolate prepared with the same SSWE. Endpoint free chlorine concentrations were taken with a chlorine meter (Hanna Instruments, Woonsocket, RI) and will be referred as to actual chlorine levels. Expected chlorine concentrations are the levels of chlorine in dilutions prepared with purified water (zero chlorine demand). Expected chlorine concentrations were related to respective actual chlorine readings using Excel Statistical. Resultant formulas then were used to project chlorine concentrations of working solutions required for chlorine assays with zoospores. A similar test also was performed with the mycelium suspension. Chlorine concentrations of treatments will be referred to as endpoint (post-mixing) free available chlorine readings in this study, unless otherwise stated.

Chlorine neutralization and its potential impact on fungal recovery. Sodium thiosulfate $\left(\mathrm{Na}_{2} \mathrm{~S}_{2} \mathrm{O}_{3}\right)$ was used to neutralize residual chlorine after the treatment period was reached. A series of dilutions corresponding to the chlorine treatments was prepared from a $0.2 \mathrm{~N}$ solution of $\mathrm{Na}_{2} \mathrm{~S}_{2} \mathrm{O}_{3}$, then the same volume of each dilution was added to respective chlorine treatment tubes to minimize the residues of $\mathrm{Na}_{2} \mathrm{~S}_{2} \mathrm{O}_{3}$. Effects of sodium thiosulfate at the highest concentration $\left(96 \mu \mathrm{N} \mathrm{Na}_{2} \mathrm{~S}_{2} \mathrm{O}_{3}\right)$, and neutralized chlorine, on Phytophthora spp. were determined with zoospores and mycelium as described above for chlorine treatments. For example, $0.5 \mathrm{ml}$ of zoospore suspension was mixed with 0.5 $\mathrm{ml}$ of the sodium thiosulfate dilution, neutralized solution, or SDW in a microtube on the mixer. An aliquot of 100 $\mu \mathrm{l}$ of the mixture then was spread in each of three 10-cm-diameter petri dishes containing PARP-V8 agar, a medium selective for pythiaceous species (13). These dishes then were incubated in the dark at $23^{\circ} \mathrm{C}$ for 2 to 7 days. Developing colonies were examined daily using a dissecting microscope, and the total number of Phytophthora colonies in each dish was recorded after 7 days. The test was repeated twice.

Mortality of zoospores. Experiments were conducted (i) to determine the effects of chlorine concentration and contact time on P. nicotianae and (ii) to evaluate chlorine sensitivity of seven Phytophthora spp. commonly found in recycled nursery irrigation water. Zoospores of P. nicotianae were exposed for five contact times $(0.25$, $0.5,1.0,2.0$, and $4.0 \mathrm{~min}$ ) to five concentrations $(0.25,0.5,1.0,2.0$, and 4.0 $\mathrm{mg} / \mathrm{liter}$ ) of chlorine plus one untreated control with SDW in the first test. Zoospores were produced by incubating mycelial plugs from a 2-week-old culture in
SSWE at $23^{\circ} \mathrm{C}$ under fluorescent light for 3 to $4 \mathrm{~h}$. The zoospore suspension was passed through eight layers of cheesecloth, and then zoospore concentration was determined with a hemacytometer and adjusted to 1,350 spores/ml with SSWE. Chlorine treatments were accomplished as described previously, and sodium thiosulfate was added to the treatment tubes immediately after the required contact time was reached to neutralize residual chlorine. Then $100 \mu \mathrm{l}$ of mixed suspension was spread in each of three 10-cm-diameter petri dishes containing PARP-V8 agar. These dishes were incubated at $23^{\circ} \mathrm{C}$ in the dark. Developing colonies were examined daily using a dissecting microscope and the total number of Phytophthora colonies was recorded after 7 days. Zoospore mortality was calculated by comparing the number of colonies in treated dishes with that in the untreated controls. The test was performed three times.

Zoospores of seven species of Phytophthora were exposed for $2 \mathrm{~min}$ to five chlorine concentrations of $0.25,0.5,1.0$, 2.0 , or $4.0 \mathrm{mg} / \mathrm{liter}$ plus a negative control with SDW in the second test. Individual species of Phytophthora were evaluated either as a group or separately, depending on the time required for sporangium and zoospore production. Zoospore suspensions were prepared and chlorine treatments were accomplished as described previously with some alterations. The zoospore concentration was increased to 17,000 spores $/ \mathrm{ml}$ for $P$. capsici, 2,730 spores $/ \mathrm{ml}$ for $P$. citricola, $6,640 \mathrm{spores} / \mathrm{ml}$ for $P$. cryptogea, and 2,730 spores $/ \mathrm{ml}$ for $P$. nicotianae $(4 \mathrm{~J} 1)$ to allow adequate numbers of colonies to develop in individual dishes. The test was repeated one to three times, depending on the Phytophthora spp.

Mortality of mycelial fragments. Five chlorine concentrations $(0.5,1.0,2.0,4.0$, and $8.0 \mathrm{mg} / \mathrm{ml})$ and five contact times $(0.5$, $1.0,2.0,4.0$, or $8 \mathrm{~min}$ ), plus an untreated control with SDW, were assessed with $P$. nicotianae for the survival of mycelia. Mycelia were harvested with a sterile cell scraper from a 4-day-old culture, then homogenized in a two-speed Waring blender at low speed for $1 \mathrm{~min}$. Chlorine treatment, subsequent culturing, and colony counting were accomplished as described previously. Mortality of mycelia was calculated by comparing the number of developing colonies in treated dishes with that in the untreated controls. The test was performed twice.

Sporangium production. Five chlorine concentrations $(0.5,1.0,2.0,4.0$, or 8.0 $\mathrm{mg} / \mathrm{liter})$ and five contact times $(0.5,1.0$, $2.0,4.0$, or $8.0 \mathrm{~min}$ ), plus an untreated control with SDW, were assessed with $P$. nicotianae for effects on sporangium production. Three 5-mm mycelial plugs taken from an actively growing area of a 4-dayold culture were submerged in $5 \mathrm{ml}$ of SSWE in a cell of a multicell petri dish, then incubated under fluorescent light at $23^{\circ} \mathrm{C}$ for $3 \mathrm{~h}$. The SSWE then was removed from each cell and replaced with 5 $\mathrm{ml}$ of chlorine solution or SDW. Chlorine was neutralized with sodium thiosulfate immediately after treatment periods were reached. Following removal of neutralized chlorine, mycelial plugs were incubated in SDW under fluorescent light for an additional $4 \mathrm{~h}$. Sporangia produced on the periphery of each mycelial plug were counted using a compound microscope. Reduction in sporangium production was calculated by comparing the number of sporangia that developed from the treated mycelial plugs with the number developed from untreated controls. The test was repeated once.

Levels of chlorine and recovery of Phytophthora spp. from irrigation water at commercial nurseries. Chlorinated and nonchlorinated water was collected monthly in 2000 and 2001 at two commercial nurseries, and quarterly in the first year at four additional nurseries in Virginia. The six nurseries have practiced recycling runoff water for at least 10 years. Phytophthora spp. were present in untreated water (3; C. X. Hong, unpublished data). Water is chlorinated by injecting chlorine into irrigation lines and treatment time from injection to emission points ranged from a few seconds to $10 \mathrm{~min}$. Levels of chlorine and of $\mathrm{pH}$ in chlorinated water were taken on site using a portable chlorine colorimeter and a Watercheck $\mathrm{pH}$ meter (Hanna Instruments). Water samples then were tested for the presence of viable propagules of Phytophthora spp. in the laboratory using a filter-based isolation method (22). Briefly, $100 \mathrm{ml}$ of irrigation water was passed through a 5- $\mu \mathrm{m}$ Durapore membrane (Millipore Corporation, Bedford, MA). Propagules retained on the filter were resuspended in $6 \mathrm{ml}$ of $0.09 \%$ sterile water agar in a test tube, then $100 \mu \mathrm{l}$ of resultant suspension was spread in each of nine 10-cm-diameter petri dishes containing PARP-V8 agar. The isolation dishes were incubated at $23^{\circ} \mathrm{C}$ in the dark and examined daily for Phytophthora spp. A portion $(25 \%)$ of colonies was subcultured and isolates were identified based on morphology (10). Water samples from which Phytophthora spp. were recovered were considered positive.

Data analyses. Data of repeated tests were pooled following homogeneity tests. Regression analyses were performed to relate expected to actual chlorine readings after mixing with pathogen suspension, using Proc REG (SAS Institute, Cary, NC). Analyses of variance (ANOVA) were conducted to determine the effect of chlorine on zoospores of individual species and isolates of Phytophthora. No comparisons were made among the species and isolates tested because they were not all assessed at the same times. ANOVA also were performed to examine the effects of 

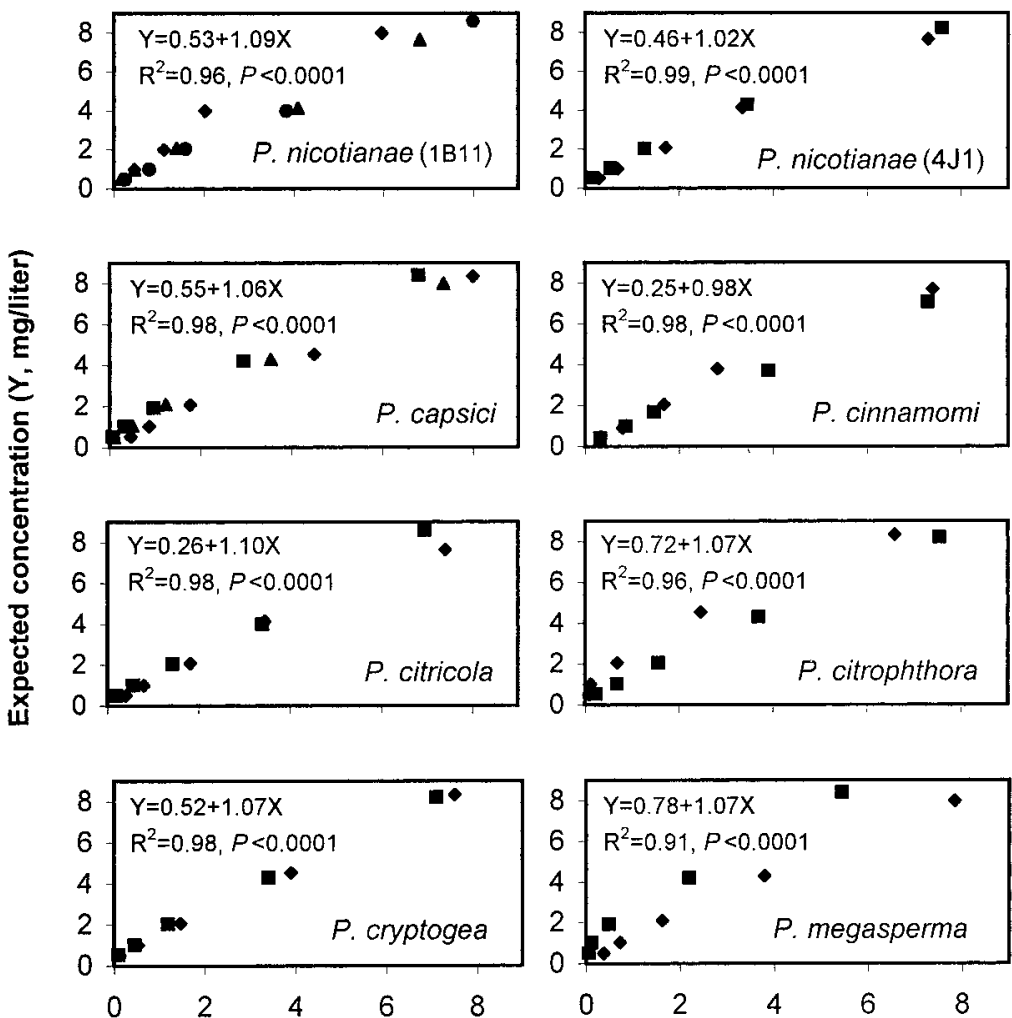

\section{Actual concentration ( $\mathrm{X}, \mathrm{mg} / \mathrm{liter}$ )}

Fig. 1. Expected and actual free available chlorine concentrations following equal mixing of zoospore suspensions of various Phytophthora spp. in $1 \%$ sterile soil water extract with concentrated chlorine solutions. Each point represents the mean of six readings. Each type of legend $(\boldsymbol{\bullet}, \mathbf{\square}, \boldsymbol{\bullet}$, or $\boldsymbol{\Delta})$ represents a test.

Table 1. Summary of linear regressions of expected against actual free available chlorine after mixing with zoospore suspension of different Phytophthora spp. in sterile soil water extract

\begin{tabular}{lcccc}
\hline Phytophthora spp. & Intercept & $\boldsymbol{P}$ & Slope & $\boldsymbol{P}$ \\
\hline P. capsici & 0.5475 & 0.0008 & 1.0609 & $<0.0001$ \\
P. cinnamomi & 0.2521 & 0.1612 & 0.9771 & $<0.0001$ \\
P. citricola & 0.2573 & 0.1869 & 1.0967 & $<0.0001$ \\
P. citrophthora & 0.7208 & 0.0297 & 1.0716 & $<0.0001$ \\
P. cryptogea & 0.5176 & $<0.0001$ & 1.0652 & $<0.0001$ \\
P. megasperma & 0.7791 & 0.0095 & 1.0680 & $<0.0001$ \\
P. nicotianae (1B11) & 0.5262 & 0.0099 & 1.0906 & $<0.0001$ \\
P. nicotianae (4J1) & 0.4577 & 0.0024 & 1.0206 & $<0.0001$ \\
\hline
\end{tabular}

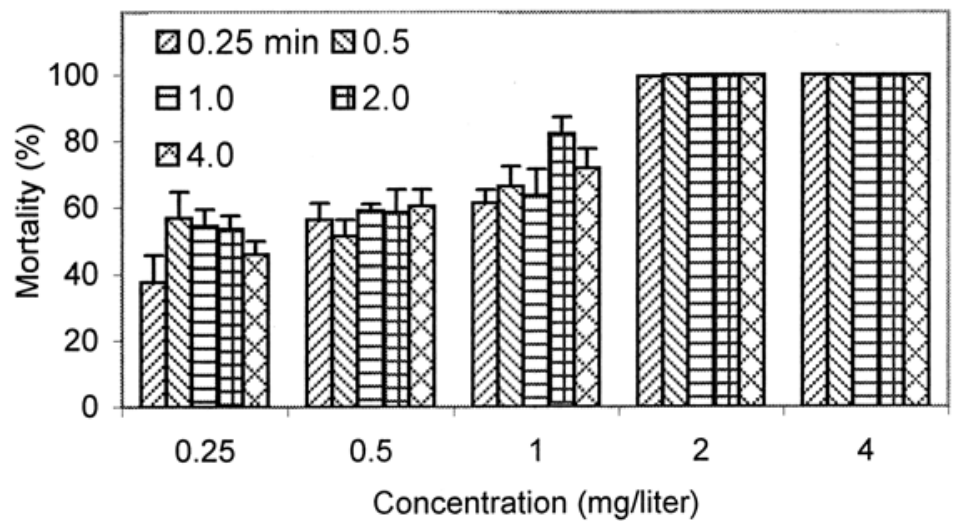

Fig. 2. Effects of chlorine concentration and contact time on the mortality of zoospores of Phytophthora nicotianae. Treated zoospores were cultured on PARP-V8 agar. Each column represents the average of three repeated tests with three samples per test. A standard error bar tops each column. chorine concentration and contact time on zoospores, mycelia, and sporangium production of $P$. nicotianae.

\section{RESULTS}

Chlorine demand of pathogen suspension. Actual chlorine readings differed significantly $(P<0.0001)$ from expected concentrations after mixing with zoospore suspensions of all species and isolates of Phytophthora (Fig. 1). The base chlorine demand was insignificant for either $P$. cinnamomi or $P$. citricola, but it was significant $(P<0.0297)$ for all other species, ranging from 0.46 to $0.78 \mathrm{mg} / \mathrm{liter}$ (Table $1)$. The chlorine demand increased $(P<$ $0.0001)$ with increasing chlorine mixed with pathogen suspension for all species except $P$. cinnamomi (Table 1 ).

Chlorine neutralization and its potential impact on fungal recovery. The number of colonies of Phytophthora that developed in untreated controls ranged from 30 to 70 colonies/dish, depending on the species tested. The recovery of Phytophthora spp. from zoospores treated with sodium thiosulfate or neutralized chlorine did not differ from that in the untreated controls. Similarly, sodium thiosulfate and neutralized chlorine had no influence on the recovery of $P$. nicotianae from mycelial fragments and sporangium production when compared with SDW (data not shown).

Mortality of zoospores. Zoospore mortality of $P$. nicotianae increased $(P<$ $0.0001)$ with increasing chlorine concentration from 0.25 to $1 \mathrm{mg} /$ liter, regardless of contact time (Fig. 2). No zoospores survived at chlorine concentrations of 2 $\mathrm{mg} / \mathrm{liter}$. Similar data were obtained with all other species and isolates tested (Fig. $3)$. No differences were observed $(P=$ $0.1411)$ in the mortality of zoospores between the range of contact times within each concentration (Fig. 2).

Mortality of mycelial fragments. Average recovery of $P$. nicotianae in untreated controls was 148 colonies/dish. The mortality of mycelia generally increased $(P$ $<0.0001$ ) with increasing chlorine concentration from 0.5 to $8 \mathrm{mg} / \mathrm{liter}$ (Fig. 4). The pathogen was recovered from mycelial fragments treated for $8 \mathrm{~min}$ with chlorine at $8 \mathrm{mg} /$ liter, although only one colony developed. Increasing contact time increased $(P=0.0021)$ mycelium mortality with chlorine at $1.0 \mathrm{mg} / \mathrm{liter}$ but not at the other concentrations tested (Fig. 4).

Sporangium production. An average of 133 sporangia were produced per mycelial plug in untreated control cells. The number of sporangia produced per plug decreased $(P<0.0001)$ with increasing chlorine concentrations from 0.5 to 8 $\mathrm{mg} /$ liter (Fig. 5). Reduction in sporangium production changed inconsistently $(P=$ 0.045) with contact times (Fig. 5).

Levels of chlorine and recovery of Phytophthora spp. from irrigation water 
at commercial nurseries. For the 40 samples assayed, levels of free chlorine in chlorinated irrigation water ranged from 0 to $8.4 \mathrm{mg} /$ liter (data not shown) and $\mathrm{pH}$ ranged from 4.2 to 8.5 . Phytophthora spp. were recovered from 10 of 40 samples assayed (Table 2). These species included $P$. citricola, $P$. citrophthora, $P$. megasperma, and $P$. nicotianae. The highest level of chlorine in irrigation water from which Phytophthora spp. were recovered was $0.77 \mathrm{mg} / \mathrm{liter}$.

\section{DISCUSSION}

As we learn more about the presence of Phytophthora spp. in irrigation water and their epidemiological and economic significance, the need for improving current chlorination protocols becomes apparent. This study examined the efficacy of chlorine on seven species (eight isolates) and three types of propagules of Phytophthora. These species commonly are found in recycled nursery irrigation water $(3,18,27,30,34,47,50)$ and are very destructive pathogens with a broad host range (10). This research is essential for assessing existing chlorination protocols and developing new protocols for control of Phytophthora pathogens.

Free available chlorine at $2 \mathrm{mg} / \mathrm{liter}(2$ ppm) at discharge (sprinklers/risers) is indicative of good control of Phytophthora spp. that may be present in irrigation water. This conclusion is supported by the fact that Phytophthora spp. were recovered only from irrigation water treated at 0.77 ppm or lower levels of chlorine. Lack of detection of Phytophthora spp. from chlorinated irrigation water with higher chlorine levels can be the result of significant pathogen reduction, but does not necessarily indicate the complete eradication of these organisms. Filter-based isolation used in these studies is the current method for quantification of Phytoph- thora spp. in irrigation water (22). It has a sensitivity limit of $33.3 \mathrm{CFU} /$ liter of water due to loss of some propagules during the filtration process. Thus, free available chlorine at $0.77 \mathrm{ppm}$ can be a good reference number but should not be used alone in developing chlorination protocols, because low population levels may not be detected.
The zoospore mortality assays elucidate the basis of the above conclusion. Zoospores are the principal, if not the sole, propagules of Phytophthora spp. in irrigation systems $(4,34,41,42,47)$. Zoospores have accounted for more than $94 \%$ of propagules for Phytophthora spp. in irrigation runoff water entering retention ponds

(4). Motile zoospores also have been the

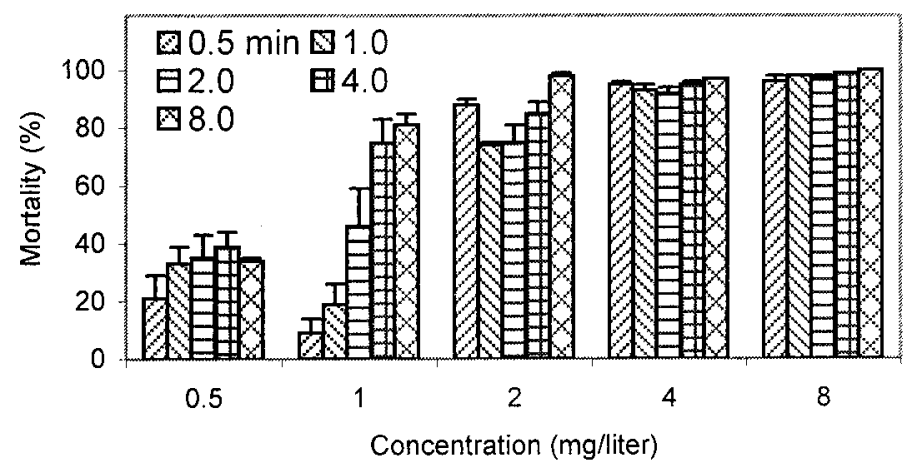

Fig. 4. Effects of chlorine concentration and contact time on the mortality of mycelial fragments of Phytophthora nicotianae. Treated mycelial fragments were cultured on PARP-V8 agar. Each column represents the average of two repeated tests with three samples per test. A standard error bar tops each column.

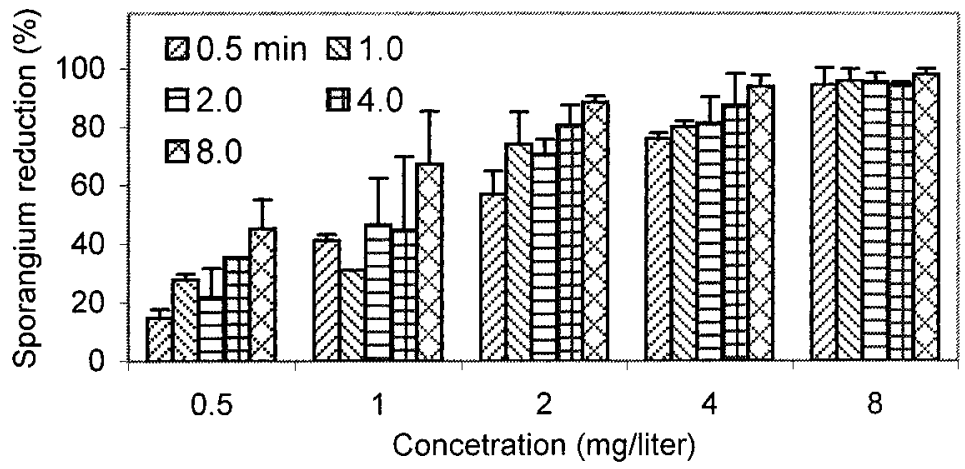

Fig. 5. Effects of chlorine concentration and contact time on the sporangium production of Phytophthora nicotianae. Each column represents the average of two repeated tests with 15 mycelial plugs per test. A standard error bar tops each column.
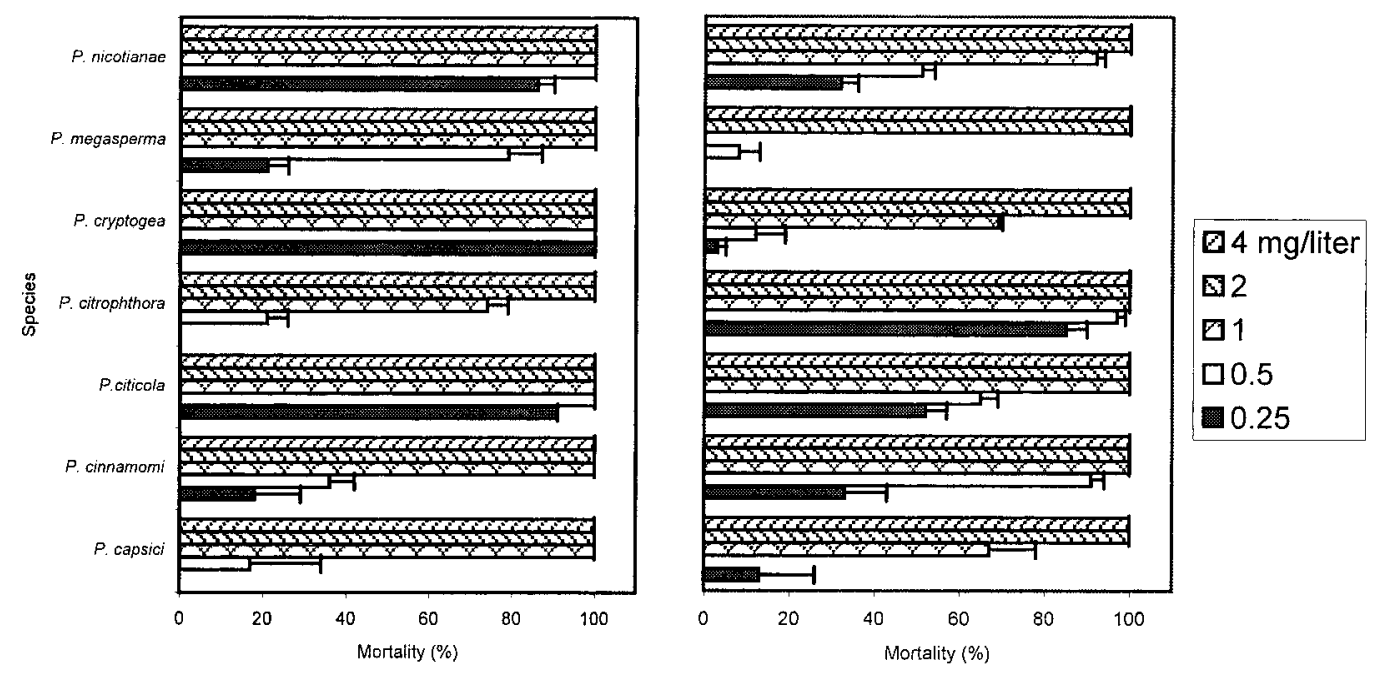

Fig. 3. Effect of chlorine concentration on the mortality of zoospores of seven Phytophthora spp. Zoospores were treated in one of the chlorine solutions or sterile distilled water for $2 \mathrm{~min}$, then cultured on PARP-V8 agar. Each column represents the mean mortality from six replicated dishes. A standard error bar tops each column. 
sole infective propagules in irrigation water responsible for natural spread of pythiaceous pathogens such as $P$. capsici (41) and $P$. aphanidermatum (42). The zoospore is the only motile propagule; other propagules, including chlamydospores, sporangia, oospores, and cysts, generally settle to the bottom of a water body (47). Thus, zoospores are the fungal structure of primary concern in water decontamination targeting Phytophthora pathogens. No zoospores of any species survived free available chlorine at $2 \mathrm{ppm}$ at any contact times in this study (Figs. 2 and 3). This threshold level is higher than in chlorinated $(0.77 \mathrm{ppm})$ irrigation water tests (Table 2). What caused this difference is not known. Pathogen concentration was greater in the zoospore mortality assays than in irrigation water tests, which may have contributed to this difference.

Some mycelial fragments treated at 8 $\mathrm{mg} /$ liter developed into colonies, although this development was minimal compared with the untreated control. Development of these colonies indicates that mycelium of $P$. nicotianae is less sensitive to chlorine than zoospores. A similar trend was reported for P. cinnamomi (40). However, if mycelia were the major propagules in irrigation water, Phytophthora spp. should have been recovered from the water samples with levels of chlorine higher than $0.77 \mathrm{ppm}$. Our nursery irrigation water tests show that this did not occur.

Sporangial production in response to chlorine changed with incubation time following the treatments. This observation has some practical implications. It must be pointed out that the data presented in this work were the number of sporangia produced $4 \mathrm{~h}$ after chlorine treatments. At that time point, the number of sporangia produced per plug decreased with increasing chlorine level. This means chlorine killed most mycelia on the surface of the plugs. Unexpectedly, the number of sporangia per plug increased with additional incubation time regardless of chlorine levels. Treated

Table 2. Levels of free chlorine and $\mathrm{pH}$ for irrigation water samples collected at commercial nurseries in Virginia and tested positive for Phytophthora spp. with filter-based isolation

\begin{tabular}{lll}
\hline Nursery, date & $\begin{array}{c}\text { Chlorine } \\
\text { (mg/liter) }\end{array}$ & pH \\
\hline A & & \\
$\quad$ March 2000 & 0.15 & 8.5 \\
May 2000 & 0 & 4.2 \\
July 2000 & 0.08 & 7.1 \\
$\quad$ October 2000 & 0.07 & 7.0 \\
B & & \\
$\quad$ March 2000 & 0.2 & 6.5 \\
April 2000 & 0.25 & 6.1 \\
June 2000 & 0.15 & 6.1 \\
C & & \\
$\quad$ August 2000 & 0.25 & 7.1 \\
D & & \\
$\quad$ November 2000 & 0.77 & 8.0 \\
June 2001 & 0.43 & 8.0 \\
\hline
\end{tabular}

and untreated mycelial plugs eventually produced the same number of sporangia (data not shown). A possible explanation of these results is that chlorine had little or no effect on mycelia buried in the agar. These mycelia grew rapidly and produced sporangia when the chlorine level was reduced. These results imply that debris or particles in irrigation systems may prevent direct contact of chlorine with fungal propagules and result in reduced chlorination efficacy. Therefore, chlorination may be more effective when used in combination with other methods, such as filtration.

Analysis of chlorine demand of SSWE provides some insight into which chlorine species to monitor and where measurement should be taken in field operations. Free available chlorine reflects the biocidal property and should be closely monitored. In contrast, total chlorine measurements can be misleading. For example, chlorination with total chlorine at 0.45 to $0.78 \mathrm{ppm}$ may have little or no effect on Phytophthora spp. because, according to the assays with SSWE (Table 1), it is more than likely that these chlorine molecules are combined by various substances and are not available for water treatment. Also due to chlorine demand, chlorine levels between injection and emission (risers or sprinklers) points can differ considerably. This difference has the potential to increase when injection of fertilizer follows chlorine injection. Thus, it is recommended that chlorine levels be monitored at discharge points (e.g., sprinklers and risers) instead of monitoring at injection points or relying on injection rate settings.

In summary, free available chlorine at 2 ppm at sprinklers or risers is required to achieve good control of Phytophthora spp. in irrigation water. Increasing free available chlorine levels to $2 \mathrm{ppm}$ at discharge points in existing chlorination protocols will minimize the risk of Phytophthora spp. present in irrigation water, reducing crop losses and the need for fungicides. Since the summer of 2001, this recommendation has benefited several nurseries in Virginia which previously used $0.5 \mathrm{ppm}$ at discharge points (8). Chlorine at $2 \mathrm{ppm}$ poses little or no risk of phytotoxicity to the majority of ornamental crops $(35,39)$. As we learn more about Pythium, Erwinia, and other species in irrigation water, additional tests of chlorine efficacy may be warranted to formulate effective chlorination protocols for a broader range of waterborne pathogens.

\section{ACKNOWLEDGMENTS}

We thank B. L. Appleton and T. J. Banko for critical reading of the manuscript.

\section{LITERATURE CITED}

1. Brennan, E., Leone, I., and Holmes, C. 1969. Accidental chlorine gas damage to vegetation. Plant Dis. Rep. 53:873-875.

2. Buck, J. W., van Iersel, M., Oetting, R., and Hung, Y. C. 2002. In vitro fungicidal activity of acidic electrolyzed oxidizing water. Plant Dis. 86:278-281.

3. Bush, E. A. 2002. Characterization of Phytophthora species in recycled irrigation water at a container nursery in Southwestern Virginia. M.Sc. thesis, Virginia Polytechnic Institute and State University, Blacksburg, VA.

4. Charlton, N. D., and von Broembsen, S. L. 2000. Survival, settling and lateral dispersal of encysted zoospores of Phytophthora spp. in captured irrigation runoff (Abstr.) Phytopathology 90:S13.

5. Cohn, D. R., and Hong, C. X. 2003. Efficacy of ultraviolet irradiance for disinfesting recycled irrigation water (Abstr.) Phytopathology 93:S123.

6. Copes, W. E., Chastaganer, G. A., and Hummel, R. L. 2001. Influence of select inorganic elements and $\mathrm{pH}$ on the fungicidal activity of chlorine dioxide in water. Proc. South. Nursery Assoc. Res. Conf. 46:284-286.

7. Datnoff, L. E., Kroll, T. K., and Lacy, G. H. 1987. Efficacy of chlorine for decontaminating water infested with resting spores of Plasmodiophora brassicae. Plant Dis. 71:734-736.

8. Daughtry, B. 1984. Chlorination of irrigation water. Combined Proc. Int. Plant Propagators' Soc. 33:596-599

9. Downey, D., Gilles, D. K., Delwiche, M. J., and MacDonald, J. D. 1989. Development and validation of a general model for predicting biological efficacy of UV reactions against plant pathogens in irrigation water. Trans. ASAE 41:849-857.

10. Erwin, D. C., and Ribeiro, O. K. 1996. Phytophthora Disease Worldwide. American Phytopathological Society Press, St. Paul, MN.

11. Ewart, J. M., and Chrimes, J. R. 1980. Effects of chlorine and ultraviolet light in disease control in NFT. Acta Hortic. 98:317-323.

12. Faulkner, L. R., and Bolander, W. J. 1966. Occurrence and largen nematode populations in irrigation canals of south central Washington. Nematologia 12:591-600.

13. Ferguson, A. J., and Jeffers, S. N. 1999. Detecting multiple species of Phytophthora in container mixes from ornamental crop nurseries. Plant Dis. 83:1129-1136.

14. Grech, N. M., Frean, R. T., and Williams, G. 1989. Ultraviolet irradiation and filtration of irrigation water in citrus and subtropical fruit nurseries. Phytophylactica 21:247-249.

15. Grech, N. M., and Rijkenberg, F. H. 1992. Injection of electrolytically generated chlorine into citrus microirrigation systems for the control of certain waterborne root pathogens. Plant Dis. 76:457-461.

16. Heald, C. M., and Johnson, A. W. 1969. Survival and infectivity of nematodes after passing through an overhead sprinkler irrigation system. J. Nematol. 1:290.

17. Hong, C. X. 2001. Effect of chlorine concentration and contact time on zoospore survival of Phytophthora nicotianae. Proc. South. Nursery Assoc. Res. Conf. 46:315-316.

18. Hong, C. X., Bush, E. A., Richardson, P. A., and Stromberg, E. L. 2002. The major deterrent to recycling irrigation water in nursery and greenhouse operations despite the lack of alternatives for limiting nonpoint source pollution. Pages 72-77 in: Proc. Va. Water Res. Symp. 2001. Blacksburg, VA.

19. Hong, C. X., and Epelman, G. 2000. Development of Phytophthora blight of vinca irrigated with contaminated water. Proc. South. Nursery Assoc. Res. Conf. 45:233-235.

20. Hong, C. X., and Epelman, G. 2001. Effect of pathogen concentration and exposure frequency on Phytophthora blight of annual vinca under drip irrigation systems (Abstr.) Phytopathology 91:S40.

21. Hong, C. X., Kong, P., and Richardson, P. A. 2002. Epidemiological significance of Phy- 
tophthora species present in recycled irrigation water to ornamental production (Abstr.) Phytopathology 92:S143.

22. Hong, C. X., Richardson, P. A., and Kong, P. 2002. Comparison of membrane filters as a tool for isolating pythiaceous species in irrigation water. Phytopathology 92:610616.

23. Johnson, C. H., Rice, E. W., and Reasoner, D. J. 1997. Inactivation of Helicobacter pylori by chlorination. Appl. Environ. Microbiol. 63:4969-4970.

24. Kliejunas, J. T., and Ko, W. H. 1976. Dispersal of Phytophthora cinnamomi on the island of Hawaii. Phytopathology 66:457-460.

25. Koenig, R. 1986. Plant viruses in rivers and lakes. Pages 321-333 in: Advances in Virus Research. Academic Press, San Diego, CA.

26. Lacy, G. H., Lambe, R. C., and Berg, C. M. 1981. Iris soft rot caused by Erwinia chrysanthemi associated with overhead irrigation and its control by chlorination. Combined Proc. Int. Plant Propagators' Soc. 31:626-634.

27. Lauderdale, C. C., and Jones, K. J. 1997. Monitoring irrigation ponds for Phytophthora sp. Proc. South. Nursery Assoc. Res. Conf. 42:225-226.

28. Le Dantee, C., Duguet, J. P., Montiel, A., Dumoutier, N., Dubrou, S., and Vincent, V. 2002. Chlorine disinfection of atypical mycobacteria isolated from a water distribution system. Appl. Environ. Microbiol. 68:10251032.

29. MacDonald, J. D., Abeliovich, A., LagunasSolar, M., Faiman, D., and Kabashima, J. 1997. Treatment of irrigation effluent water to reduce nitrogenous contaminants and plant pathogens. Final Report of BARD Project No. US-2122-92. Bet Dagan, Israel.

30. MacDonald, J. D., Ali-Shtayeh, M. S., Kabashima, J., and Stites J. 1994. Occurrence of Phytophthora species in recirculated nursery irrigation effluents. Plant Dis. 78:607-611.

31. Moorman, G. W., Kang, S., Geiser, D. M., and Kim, S. H. 2002. Identification and characterization of Pythium species associated with greenhouse floral crops in Pennsylvania.
Plant Dis. 86:1227-1231.

32. Norman, D. J., Yuen, J. M. F., Resendiz, R., and Boswell, J. 2003. Characterization of Erwinia populations from nursery retention ponds and lakes infecting ornamental plants in Florida. Plant Dis. 87:193-196.

33. Phillips, D. J., and Grendahl, J. 1973. The effect of chlorinating hydrocooling water on Monilinia fructicola conidia and brown rot. Plant Dis. Rep. 57:814-816.

34. Pittis, J. E., and Colhoun, J. 1984. Isolation and identification of pythiaceous fungi from irrigation water and their pathogenicity to $\mathrm{An}$ tirrhinum, tomato, and Chamaecyparis lawsoniana. Phytopathol. Z. 110:301-318.

35. Poncet, C., Offroy, M., Bonnet, G., Brun, R., and Zieslin, N. 2001. Disinfection of recycling water in rose cultures. Acta Hortic. 547:121-126.

36. Robinson, I., and Adams, R. P. 1978. Ultraviolet treatment of contaminated irrigation water and its effect on the bacteriological quality of celery at harvest. J. Appl. Bacteriol. 45:83-90.

37. Runia, W. T., Michielsen, J. M. G. P., van Kuik, A. J., and van Os, E. A. 1996. Elimination of root-infecting pathogens in recirculation water by slow sand filtration. ISOSC Proc. 395-407.

38. Segall, R. H. 1968. Fungicidal effectiveness of chlorine as influenced by concentration, temperature, $\mathrm{pH}$, and spore exposure time. Phytopathology 58:1412-1414.

39. Skimina C. A. 1992. Recycling water, nutrients, and waste in the nursery industry. HortScience 27:968-971.

40. Smith, P. M. 1976. Control of P. cinnamomi in water by chlorination. Page 112 in: Glasshouse Crops Res. Inst. Annu. Rep. LittleHampton, England.

41. Stanghellini, M. E., Kim, D. H., Rasmussen, S. L., and Rorabaugh, P. A. 1996. Control of root rot of peppers caused by Phytophthora capsici with a nonionic surfactant. Plant Dis. 80:1113-1116.

42. Stanghellini, M. E., Rasmussen, S. L., Kim, D. H., and Rorabaugh, P. A. 1996. Efficacy of nonionic surfactants in the control of zoospore spread of Pythium aphanidermatum in a recirculating hydroponic system. Plant Dis. 80:422-428.

43. Stanghellini, M. E., and Tomlinson, J. A. 1987. Inhibitory and lytic effects of a nonionic surfactant on various asexual stages in the life cycle of Pythium and Phytophthora species. Phytopathology 77:112-114.

44. Taylor, R. H., Falkinham, J. O., Norton, C. D., and Lechevallier, M. W. 2000. Chlorine, chloramine, chlorine dioxide, and ozone susceptibility of Mycobacterium avium. Appl. Environ. Microbiol. 66:1702-1705.

45. Thinggaard, K., and Middelboe, A. L. 1989. Phytophthora and Pythium in pot plant cultures grown on ebb and flow bench with recirculating nutrient solution. J. Phytopathol. 125:343-352

46. Thompson, D. L. 1965. Control of bacterial stalk rot of corn by chlorination of water in sprinkler irrigation. Crop Sci. 5:369-370.

47. Thomson, S. V., and Allen, R. M. 1974. Occurrence of Phytophthora species and other potential plant pathogens in recycled irrigation water. Plant Dis. Rep. 58:945-949.

48. von Broembsen, S. L. 1984. Distribution of Phytophthora cinnamomi in rivers of the southwestern Cape province. Phytophylactica 16:227-229.

49. von Broembsen, S. L., and Deacon, J. W 1997. Calcium interference with zoospore biology and infectivity of Phytophthora parasitica in nutrient irrigation solutions. Phytopathology 87:522-527.

50. von Broembsen, S. L., and Wilson, S. K. 1998. Occurrence of Phytophthora spp. in nursery runoff and recycled irrigation water (Abstr.) Phytopathology 88:S92.

51. White, G. C. 1999. The Handbook of Chlorination and Alternative Disinfectants. J Wiley, New York.

52. Yamamoto, H., Terada, T., and Naganawa, T. 1990. Disinfectious effect of ozonation on water infested with several root-infecting pathogens. Ann. Phytopathol. Soc. Jpn. $56: 250-251$. 